Przemystaw Jastrzębski

Katedra Nauk Społecznych

Szczecińska Szkoła Wyższa

Collegium Balticum

\title{
Wschodni model współczesnego wychowania państwowego na przykładzie rosyjskiego korpusu kadetów. Zarys problemu
}

\begin{abstract}
Przemysław Jastrzębski, Eastern model of the modern state education on the example of the russian cadet corps. Outline of the problem

The modern model of state education in Russia promotes patriotism and devotion to the authorities. Young people must be proud of their origin and, in spite of deteriorating material conditions, should stay in the country contributing to its development. Cadet Corps Alumni are an example of a patriotic education model. Several years of learning in the military school shapes their beliefs and teaches them complete surrender to authority. Patriotism, combined with the sense of external threat, has become the driving force behind the reconstruction of the Russian superpower. One of the cornerstones of the school is the acceptance of Putin's Russia by spreading the vision of becoming an international representative of the country. The increase in military spending and functioning of military schools such as the Corps of Cadets give rise to fears that in the future Russia the army will become one of the tools of the superpower on the arena of foreign policy.
\end{abstract}

Keywords: Russia, Central-East Europe, New Partiotizm, Army, National Education

Współczesne wychowanie państwowe na Wschodzie, a zwłaszcza w Rosji, ma na celu zaszczepienie wśród młodego pokoleniu wiary w potęgę ich kraju. Erozja ZSRR spowodowała osłabienie znaczenia i autorytetu armii, która straciła swoją świetność, wchodząc w erę poważnego kryzysu ${ }^{1}$. Jego przejawem stał się konflikt w Czeczenii z 1994 r., który w pełnej okazałości obnażył opłakany stan rosyjskich sił zbrojnych. Na front wysłano oddziały słabo wyszkolone, często zdemoralizowane, odreagowujące porażki i stres bojowy agresją w koszarach. Konflikt czeczeński przyniósł armii rosyjskiej nie tylko wymierne straty osobowe i materialne, ale także gwałtownie nadszarpnął wizerunkiem wojska².

1 Por.: G. Pazura, Wspótczesne konwencjonalne sity zbrojne Federacji Rosyjskiej, Lublin 2010, s. 33.

2 Zob. więcej: I. Topolski, Siła militarna w polityce zagranicznej Federacji Rosyjskiej, Lublin 2004; A. Babczenko, Dziesięć kawałków o wojnie, Warszawa 2009. 
W efekcie podjęto wysiłki mające służyć odbudowaniu pozycji armii, które zostały szczególnie zintensyfikowane wraz z objęciem w 2000 r. stanowiska Prezydenta Federacji Rosyjskiej przez Władymira Putina. Przejawem takiego stanu rzeczy stało się pięciokrotne zwiększenie wydatków na armię. Dwukrotnie wzrosły środki przeznaczane na żołnierski żołd. Jednym z elementów rekonstrukcji wizerunku rosyjskiej armii był dekret Putina na rzecz propagowania patriotyzmu wśród młodych Rosjan ${ }^{3}$. Odbudowa pozycji i znaczenia armii stały się jednym z priorytetów władz rosyjskich. W Rosji pokutuje przeświadczenie, że odbudowa dawnej potęgi militarną stanie się jednym ze środków zapewniającym równorzędne relacje z $\mathrm{USA}^{4}$.

Propagowanie nowego patriotyzmu zostało przez rosyjskie władze uznane za pierwszy, niezmiernie ważny krok ku odnowie sił wojskowych, a szerzej kształtowaniu postaw państwowych. W konsekwencji tego, w całym kraju zaczęły powstawać wojskowe szkoły średnie kształcące przyszłych oficerów, często wizytowane przez przedstawicieli najwyższych władz rosyjskich. Postanowiono wykorzystać fakt, że armia stała się dla wielu młodych Rosjan nierzadko jedyną możliwością na uzyskanie zawodowego oraz społecznego awansu. Dobre zarobki i gwarancja stałego zatrudnienia wpływają na rosnącą popularność wojskowych szkół średnich organizowanych w ramach Korpusu Kadetów. Już ponad połowa jego absolwentów trafia do prestiżowych akademii wojskowych i robi karierę $\mathrm{w}$ armii ${ }^{5}$.

Dalekosiężnym planem władz Federacji Rosyjskiej jest zwiększenie armii do stanu wynoszącego $1 \mathrm{mln}$ żołnierzy w bezpośrednim oparciu o zasoby kadrowe ukształtowane za pomocą Korpusu Kadetów. Od momentu objęcia przez Putina urzędu prezydenta Rosji liczba kadetów stale się zwiększa. Obecnie są oni kształceni w ponad stu specjalnie ku temu przygotowanych placówkach. Często rekrutami stają się chłopcy posiadający rodzinne tradycje wojskowe i przez to od dziecka kształtowani w kulcie dla armii rosyjskiej. Zasadniczym celem większości kadetów jest dalsze kształcenie wojskowe w rosyjskich wyższych akademiach wojskowych ${ }^{6}$.

Podstawą kadeckiego kształcenia jest wpajanie patriotyzmu i bezkrytycznego stosunku do ojczyzny, czemu mają służyć chociażby zajęcia muzyczne polegające na skomponowaniu przez kadetów piosenek o odpowiednim w treści i formie charakterze. Kadeci jako przyszli rekruci rosyjskiej armii poddawani są w związku z tym niezwykle silnemu wychowaniu państwowemu, którego zasadniczą cechą staje się formacja ideologiczna bazująca na bezwarunkowym posłuszeństwie i lojalności wobec władzy. W efekcie stają się oni jednym z fundamentów rosyjskiego systemu politycznego. Widoczne było to podczas moskiewskiej defilady w maju z 2008 r., która odbyła się z licznym udziałem kadetów z rosyjskich szkół wojskowych.

\footnotetext{
3 Na podstawie http://www.ruscadet.ru/ [11.02.2012].

${ }^{4}$ A. Woźniak, Radziecki model wychowania powraca. Tekst dostępny na: http://eastbook.eu/2010/03/country/ belarus/bialorus26-03-2010-radziecki-model-wychowania-powraca-na-bialorus/ [10.02.2012].

5 А.О. Хазин, Пажи, кадеты, юнкера, 2002, с. 12.

${ }^{6} \mathrm{Na}$ podstawie reportażu Ewy Ewart Dzieci Putina z października 2010 r. wyemitowanego dla stacji TVN. Reportaż dostępny na stronie: http://www.youtube.com/watch?v=nHZKHmOa-o4 [10.02.2012].
} 
Flagową jednostką systemu jest Doński Kadecki Korpus im. Imperatora Aleksandra III w Nowoczerkasku - niegdyś głównej siedziby dońskich wojsk kozackich. Założyciel miasta, ataman Matwiej Płatow, bohater wojny ojczyźnianej 1812 r., w Nowoczerkasku polecił na jej pamiątkę wybudować tryumfalne łuki zwycięstwa. To w Nowoczerkasku rodziła się Biała Gwardia i formowała Ochotnicza Armia gen. Ławra Gieorgijewicza Korniłowa - stanowiąca trzon „białego” oporu wobec bolszewików, w efekcie czego na miasto spadły drastyczne represje - rozkozaczanie, rozkułaczanie, rozstrzeliwanie i głód. Po 1962 r. władza sowiecka nie zainwestowała w Nowoczerkask ani kopiejki, co stanowiło odwet za strajk robotników z fabryki elektrowozów, którzy domagali się poprawienia warunków zaopatrzenia sklepów oraz regularnych wypłat nadgodzin. Demonstracja robotników została krwawo spacyfikowana przez siły bezpieczeństwa. Liczbę ofiar, szacowaną na 80 osób, do dziś trudno precyzyjnie zweryfikować, wobec wywożenia przez władze ciał poza miasto i organizowania nocnych pochówków w leśnych dołach ${ }^{7}$.

Obecnie dzięki szkole kadetów miasto stara się odzyskać dawną świetność. Nowoczerkaski korpus zyskał sobie opinię jednej z najlepszych tego typu szkół w Rosji. Jej początki związane są z inicjatywą grupki zapaleńców, którzy w październiku 1991 r. najpierw zorganizowali szkołę niedzielną, gdzie uczono religii, historii kozactwa oraz prawdy o sowieckich prześladowaniach, jakie spadły na doński kraj. Z czasem wprowadzono mundury z 1914 r., dwugłowe orły oraz kozackie stopnie. Głównym organizatorem szkoły był Oleg Nikołajewicz - emerytowany pułkownik armii sowieckiej, bohater Wielkiej Wojny Ojczyźnianej i Związku Radzieckiego, oficer sztabu 5 Dońskiego Pułku Gwardyjskiego, który zwycięsko przeszedł szlak bojowy, kończąc go w maju 1945 r. w Austrii, wreszcie syn kozaka, straconego przez bolszewików na Syberii za służbę w białych oddziałach Denikina. Niebagatelną rolę odegrał również Wiktor Mieronow - także były pułkownik sowieckiej armii. Dzięki jego staraniom korpus uzyskał budynek oraz statut szkoły społecznej, a w końcu państwowej. Aby pokryć pierwsze wydatki szkoły zdecydował się na sprzedaż własnego domu. Dzięki staraniom Mieronowa korpus zdołał pozyskać możnych protektorów: gen. Aleksandra Lebiedzia, który sam pochodzi z kozackiej rodziny i urodził się w Nowoczerkasku, oraz Aleksego Jordana, prezydenta związku rosyjskich kadetów na uchodźstwie, którego syn milioner powrócił do Rosji i kieruje potężną telewizją NTW. Z inspiracji Jordana - juniora powstała fundacja, która wspiera odradzające się w Rosji korpusy kadeckie ${ }^{8}$.

Kształcenie w szkole kadetów trwa obecnie siedem lat, czyli niemal całe dzieciństwo młodych chłopców (junost). Szczególny nacisk kładziony jest na dyscyplinę i punktualność. Wśród kar stosuje się upomnienia, nagany, nakaz pozostania w internacie w weekend, pozbawienie prawa noszenia pagonów i noszenia munduru oraz wydalenie ze szkoły. Dyscyplinowanie odbywa się podczas porannego apelu w obecności kolegów - kadetów. Występujący przed szereg kadet jest pouczany przez oficera wychowawcę co do znaczenia i istoty swojego przewinienia. Poprzez upokorzenia karanego wśród kadetów wyrabiane

\footnotetext{
${ }^{7}$ Н. Рузанова, С чужого плеча. Имеют ли право руководители кадетов называть себя генералами, „Российская газета” №5106 (27) от 10.02.2010.

${ }^{8}$ I.T. Miecik, Kadet uczy się Rosji, „Polityka” 05.01.2002 r., nr 1 (2331), s. 93.
} 
jest, szczególnie cenione w kształceniu proponowanym przez korpus, bezwzględne posłuszeństwo i posłuch wobec przełożonych ${ }^{9}$. Zwyczajowo dzień rozpoczyna się pobudką o 6.30, po której następuje poranny apel i wywieszenie flagi na maszt. Szkołę tworzą sotnie podzielone na klasy-plutony. W placówce w Nowoczerkasku istnieją dwie sotnie, w skład których wchodzi podzielone na 16 plutonów złożonych z siedmiu roczników od 10 do 17 lat, co w sumie daje 320 kadetów $^{10}$.

Kluczową funkcję w wychowaniu młodych pełnią pułkownicy wychowawcy. Każdy oficer opiekuje się swoją klasą-plutonem i prowadzi ją aż do zakończenia szkoły. W większości są oni emerytowanymi wojskowymi silnie identyfikującymi się z patriotyzmem i służbą dla Rosji ${ }^{11}$. Znacząca liczba obecnych wychowawców i dowódców w Korpusach Kadetów legitymuje się kozackimi korzeniami ${ }^{12}$.

Niezwykle istotnym czynnikiem kształtowania odpowiednich postaw jest rosyjska historia ukazywana w odpowiednim świetle. W holach Korpusów Kadetów wszechobecne są popiersia lub obrazy wybitnych rosyjskich dowódców. Kształcenie historyczne jest niezmiernie rozbudowane, szczególnie w odniesieniu do dziejów rosyjskiej wojskowości. Umiejętnie akcentowane są wszelkie sukcesy rosyjskiego oręża w przeszłości. Szczególną w tym względzie estymą cieszą się dzieje oddziałów kozackich, których oddanie wobec cara, modelowy patriotyzm i niezwykła waleczność stawiana jest za wzór kadetom. Wychowanie patriotyczne odbywa się przez umiejętne przekazywanie starannie wyselekcjonowanych treści historycznych często podawanych w specyficznej interpretacji:

W nauce historii ważne jest to, żeby umieć wyciągać z przeszłości wnioski. Powtórzmy więc panowie, co powiedzieliśmy sobie dziś o przyczynach wybuchu pierwszej wojny światowej, a z czego możemy jednocześnie wyciągnąć dla siebie naukę. Po pierwsze, Niemcy, niewielki podzielony kraj, urosły do rangi mocarstwa przede wszystkim dzięki żelaznej dyscyplinie pracy klasy robotniczej. Dyscyplina i porządek, panowie, to źródło potęgi państw i narodów. Pierwsza wojna jak wszystkie miała jedną główną przyczynę - chęć zdobycia przez jedno państwo bogactwa wypracowanego przez obywateli drugiego. Każda kolejna wojna jest coraz straszniejsza. Dlatego pamiętajcie, panowie, trzecia wojna światowa będzie zarazem ostatnią. My Rosjanie to rozumiemy, stąd właśnie wzięła się pokojowa doktryna Związku Radzieckiego - nie dopuścić do trzeciej wojny. Ale o tym będziemy się uczyć w przyszłym roku'13.

Szczególne znaczenie w kształceniu kadetów posiada tradycja kozacka. Obecnie jest ona kultywowana już w około 30 placówkach kadeckich w Rosji, stając się podstawą działań dydaktycznych i wychowawczych. Na zakończenie nauki w Korpusie Kadetów absolwenci składają przysięgę wzorowaną na kozackiej, która obwiązywać ma ich przez całe życie:

Będę uczciwy, będę bronić słabych, nigdy nie zdradzę swoich towarzyszy. Jesteśmy przyszłościa Rosjil ${ }^{14}$.

\footnotetext{
9 Н. Рузанова, ор. cit.

${ }^{10}$ I.T. Miecik, op. cit., s. 92.

11 Ibidem, s. 93.

12 E. Ewart, Dzieci Putina,

13 I.T. Miecik, op. cit., s. 94.

14 E. Ewart, Dzieci Putina".
} 
Z tych powodów duży akcent kładziony jest na wychowanie etyczno-moralne. Absolwenta korpusu kadetów powinny cechować nienaganne maniery, elegancja i taktowność oraz gorący patriotyzm, ale nie szowinizm. Jeśli zostanie oficerem, to będzie stanowczy wobec wrogów, ale szlachetny wobec pokonanych, jeśli cywilem - będzie uczciwym kontrahentem, sumiennym pracownikiem, sprawiedliwym i wyrozumiałym szefem. Będzie świadomy drogi, jaką przez tysiąc lat kroczyła jego ojczyzna, sam zaś będzie służył innym za przykład. Kadeci biegle posługują się angielskim i francuskim, zwykle są wolni od nałogów, prowadzą sportowy tryb życia. Wielu z nich planuje swoją dalszą kariera w stolicy - ich marzeniem są studia w wyższej szkoły FSB (dawniej KGB) i praca W służbach ${ }^{15}$.

W korpusie ważne miejsce przeznaczone jest na religię - kadeci modlą się rano, wieczorem i przed posiłkami, razem z nimi modlą się oficerowie-wychowawcy. Niektórzy z kadetów przechodzą w Korpusie rzeczywiście wewnętrzne przebudzenie. W większości przypadków zajęcia z religii traktowane są przez kadetów jako kolejny z obowiązków wynikający z kształcenia patriotycznego ${ }^{16}$. Także podczas zajęć z katechezy, niezależnie od formacji duchowej, kadeci są uświadamiani o roli i posłannictwie, jakie będą zobowiązani spełnić we współczesnej Rosji:

Jesteście pierwszymi Rosjanami, którzy nie pamiętają Związku Sowieckiego, wy będziecie budować nową Rosję. Dopiero kiedy opuścicie mury szkoły i zaczniecie dorosłe życie, będzie wiadomo, co wynieśliście z korpusu. Tylko własnym życiem pokażecie, czy Doński Kadecki Korpus rzeczywiście znów istnieje, czy wszystko to tylko parę lat przebierania się w stroje ludowe ${ }^{17}$.

Kadeci wychowywani od małego w mundurze, w wojskowej dyscyplinie i przez wojskowych w przyszłości mają być elitą intelektualną i moralną nowego rosyjskiego społeczeństwa. Nie przeszkadza to, aby czerpali z imperialnej tradycji carskiej Rosji i dokonań Związku Radzieckiego. Dlatego wzorcami mogą być dla nich ataman Bakłanow - dziewiętnastowieczny pogromca Czeczenów, Aleksandr Bestużew, generał Ławr Korniłow, generał Michaił Kutuzow czy marszałek Gieorgij Żukow ${ }^{18}$.

Nowe rosyjskie wychowanie państwowe przez swój charakter może budzić uzasadnione kontrowersje. W szczególności dotyczą one zbyt daleko idącym ograniczeniom indywidualizmu kadetów, w tym prezentowania samodzielnych, suwerennych postaw intelektualnych. Wszelkie próby idące w tym kierunku tłamszone są w zarodku i kończą się z reguły wydaleniem ze szkoły. W efekcie dominującymi postawami kadetów jest bezwolność i bezkrytyczność wobec swych nauczycieli oraz wychowawców. Indywidualiści nieumiejący podporządkować regułom panującym w korpusie są odsuwani od kształcenia $^{19}$.

\footnotetext{
15 A. Woźniak, op. cit.

16 Н. Рузанова, ор. cit.

17 I.T. Miecik, op. cit., s. 96.

18 A. Woźniak, op. cit.

19 E. Ewart, Dzieci Putina.
} 
Warto także zauważyć, że w swoich ogólnych tendencjach nowe wychowanie patriotyczne wpisuje się w narastające w Rosji ogólne tendencje szowinistyczne i nacjonalistyczne, które - pomimo oficjalnych deklaracji - w imię kształtowania postaw patriotycznych i państwowych nierzadko znajdują akceptację także w Korpusie Kadetów. W efekcie organizacja „Matki żołnierzy” prowadzi kampanię społeczną sprzeciwiającą się powszechnemu poborowi do armii, w której mnożą się przykłady agresji, a nawet śmiertelnych pobić wśród żołnierzy. Oficjalna, państwowa akceptacja dla tego typu postaw powoduje coraz częstsze zjawiska nietolerancji i rasizmu ujawniające się w Rosji pod patriotycznymi hasłami skierowanymi chociażby przeciwko mniejszościom azjatyckim. Dlatego zdaniem przedstawicieli organizacji pozarządowych w Rosji konieczna jest realna cywilna kontrola nad armią, która zapanowałaby nad wynaturzaniem znaczenia patriotyzmu i jego zawłaszczaniem przez siły zbrojne ${ }^{20}$.

Wzorem Rosji również inne kraje wschodnie starają się wdrożyć nowy model wychowania państwowego. Białoruskie władze zapowiedziały np. wprowadzanie nowego programu wychowania społecznego obywateli kraju. Ma on objąć swym zakresem osoby pomiędzy 6 a 70 rokiem życia. Za realizację odpowiadać ma białoruskie Ministerstwo Sportu i Turystyki, które swoje działania planuje rozpocząć od uczniów, studentów. Model białoruski wzorowany jest na programie funkcjonującym w ZSRR w latach 1931-1991 pod nazwą „Gotowy do pracy i obrony” (GTO). Wówczas to poszczególne stopnie doskonalenia musieli zdobywać wszyscy podczas masowych zawodów sportowych. Nowa koncepcja wychowania zakłada 6 etapów rozwoju. Dzieci do lat 10 będą zdobywały sprawność „Olimpijska nadzieja”. Od 10 roku życia można będzie otrzymać odznaki: „Sportowa zmiana”, „Sprawny fizycznie” i „Obrońca ojczyzny”. Kobiety od 30 do 39 roku objęte będą programem ,Zdrowie i uroda"21.

Model wychowania państwowego realizowanego przez Korpusy Kadetów ma na celu ukształtowanie nowego pokolenia rosyjskich patriotów gotowych do bezwarunkowego poświęcenia się dla ojczyzny, służby na rzecz kraju oraz dbałości o jego rozkwit. Kadeci mają przesiąknąć duchem mocarstwowości ich ojczyzny i głębokim przekonaniem o wyjątkowości Rosji na arenie międzynarodowej. Wychowanie kadetów opiera się na ich absolutnym podporządkowaniu wychowawcom i bezkrytycznym stosunku wobec przekazywanej im wiedzy. Każdy przejaw krytycyzmu i objaw samodzielności spotyka się z brakiem akceptacji ze strony wychowawców.

Obecnie w składzie rosyjskich sił zbrojnych znajduje się około 70 tys. ochotników. W przyszłości Putin chce stworzyć z ochotników milionową armię świetnie wyszkolonych żołnierzy gotowych do oddania życia za swój kraj. Podstawą ku temu jest wychowanie państwowe, które ma zapewnić rekrutom odpowiednią motywację do wstępowania do armii. Wychowanie patriotyczne w Rosji przynosi efekty, czego dowodem była reakcja obywateli tego kraju na atak wojsk rosyjskich na Gruzję w 2008 r. Większość z nich popierała działania swego kraju i argumentowała to tym, iż USA i Europa dążyły do upokorzenia Rosji.

\footnotetext{
${ }^{20}$ A. Woźniak, op. cit.

${ }^{21}$ Ibidem.
} 
Współczesny model wychowania państwowego w Rosji promuje patriotyzm i oddanie władzy. Młodzi ludzie mają być dumni ze swego pochodzenia i mimo gorszych warunków materialnych powinni zostawać w ojczyźnie, przyczyniając się do jej rozwoju. Wychowankowie Korpusu Kadetów są przykładem wzorcowego wychowania patriotycznego. Kilkuletnia nauka w szkole wojskowej kształtuje ich przekonania i uczy całkowitego podporząakkowania władzy. Patriotyzm potęgowany poczuciem zewnętrznego zagrożenia ma stać się siłą napędową odbudowy rosyjskiego supermocarstwa.

Jedną z podstaw akceptacji Pupina w Rosji jest roztaczanie przez niego wizji restauracji międzynarodowej pozycji kraju. Wzrost wydatków na armię i funkcjonowanie szkół wojskowych, takich jak Korpusy Kadetów, daje podstawy do obaw, że w przyszłości Rosja uczyni armię jednym z narzędzi swojej mocarstwowej polityki na arenie zagranicznej. 
